\title{
Bioprocess engineering and genetically modified foods: tackling food insecurity in Africa
}

\section{Oluwadamilola Matthew Makinde ${ }^{1}$ Osebhahiemen Odion Ikhimiukor $^{2 * *}$ and Stephen Fapohunda ${ }^{1}$}

${ }^{1}$ Department of Microbiology. School of Science and Technology. Babcock University. Ilishan Remo. Nigeria.

${ }^{2}$ Environmental Microbiology and Biotechnology Laboratory. Department of Microbiology. University of Ibadan. Nigeria.*Email: odionikh@gmail.com.

\begin{abstract}
Bioprocess engineering today has made tremendous discoveries principally aimed at improving the overall quality of living of any society. Significant of these discoveries is the cultivation of genetically modified foods (GM foods). This paper discusses the problem of food security in sub-Saharan Africa (SSA) and the practicability of GM foods in ameliorating this problem. In SSA, food security is currently being threatened by several factors ranging from natural systems that cause environmental deterioration such as floods and droughts to anthropogenic exacerbations ranging from poor land and agricultural management policies; increase in social and economic inequality; terrorism, civic unrest, strife and wars and rapid population growth and demographic changes, amongst others. Drawbacks to the poor food security in SSA is majorly associated with malnutrition and corresponding loss in human capita productivity in the region. Statistics currently portray that one in four persons in Africa is undernourished. Hence, the timely need for disruption in current trends is imperative. The growth of GM foods has seen an exponential increase worldwide, with over 179.7 million hectares being planted, this trend is however very poor in SSA. The pros, cons and hindrances influencing the use of GM foods in SSA have been discussed. It is the opinion of the authors that the use of Biotech improved foods in curbing the food crisis in SSA should be explored and committed to by the African Union, alongside amendment of policies that promulgate weaknesses of agricultural institutional in African Nations.
\end{abstract}

Keywords: Bioprocess engineering; Genetically modified foods; Food security; Sub-Saharan Africa; Malnutrition.

\section{Introduction}

\begin{abstract}
A bioprocess often engages a living organism as a whole or a cell or other subcellular fragments. It involves the whole procedure involving cultivating the cells. Its
\end{abstract}

Received

October 29, 2017

Accepted

December 10, 2017

Released

December 31, 2017

Open Access Full Text Article

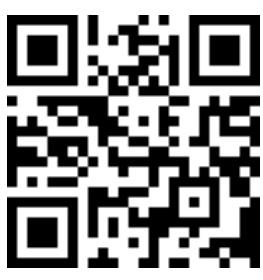

ORCID

(ㄱ) 0000-0003-0023-8708

Oluwadamilola Matthew Makinde

(ㄷ) 0000-0002-3738-4584 Osebhahiemen Odion Ikhimiukor

(D) 0000-0001-5245-1020

Stephen Fapohunda 
Downstream processing takes charge of cell separation from the culture medium immediately after the desired growth is achieved and all other steps aimed at separation, purification and product polishing. In metabolomics which involves the investigation of the metabolites in a cell, improvement of strain can be achieved by using bioprocess engineering. It is now equally possible to use a high density 3-dimensional cell cultures to test toxicity of drugs without recourse to animal models (Markov, 2012). Bioprocess engineering drives biotechnology and therefore critical in bioreaction and fermentations steps. This makes the discipline very relevant in pharmaceutical, food and agriculture, environmental, biofuel and animal and cell cultures (Markov, 2012).

Due to the huge role bioprocess can play in agriculture, there is a need to explore its use towards the development of agricultural sector. Adegbola et al. (2011) stresses this fact that the development of the agricultural institutions of any country acts as a significant boost to its overall national development. In contrast, systems with weak agricultural institutions run into crisis of food due to its inability to cope adequately by matching its demand with supply. Hence, attaining food security is crucial to any country (Ojo and Adebayo, 2012). The conceptualization of food security has previously been expatiated upon (Boon, 2009; Ojo and Adebayo, 2012; Otaha, 2013).

According to UNEP (2002), food security is described as the provision of secure and safe, nourishing, quality and quantity adequate food, which is accessible by everyone. Similarly, Idris et al. (2008) sees food security as having sufficient food and food products that matches the increasingly high demand as well as acts as a buffer to fluctuations in output and pricing at all times. In these definitions, the common term to food security is its sufficiency, accessibility and nutritious capacity of food, the opposite of which can be referred to as food insecurity, defined by Maharjan and Chhetri (2006) as the inaccessibility to qualitatively and quantitatively sufficient, safe and nutritious food for healthy living. Food insecurity epitomizes the challenge posed by changes in income, price and production on the ability of individuals, homes and communities to meet their demand for food. On the average an African farmer produces less than 1.3 tons of cereals per hectare, which is less than half and quarter of that produced by a farmer in South Asia and China on the same expanse of land, respectively (Wedding and Tuttle, 2013). Critical to improving Africa's food security requires the political will to increase the agricultural production levels of African farmers.

\section{Challenges of food security in Africa}

In the struggle to attaining a food secure continent, sub-Saharan Africa (SSA) faces a number of critical challenges, a few of them include environmental deterioration which may lead to environmental disasters like floods and droughts resulting from poor land policies and management practices; Increase in social and economic inequality in the continent; Terrorism, civic unrest, strife and wars; rapid dynamics in the global economy; rapid population growth and demographic changes (UNEP 2002; Agyare-Kwabi, 2003; Boon, 2009; Hilderink et al., 2012; FAO, 2015; Vahyala et al., 2016).

Africa having a population growth rate of 2.7 percent per annum has seen considerable increase in its population size, from 507 million in 1990 to about 936 million inhabitants in 2013 (FAO, 2015). Population size in Africa in the near future is projected to double alongside continuance in the high economic growth rates (World Bank, 2011; FAO, 2015). Since the 1960's, observed agricultural output has not been commensurate with the population growth (Boon, 2009), and according to projections by OECD/PBL, demand for food in Africa will increase by a factor of four to five by 2050 (Hilderink et al., 2012). As a result of insufficiency of food items and raw materials, African countries have become major import destinations of food. For example, Nigeria which used to be a major exporter of 
agricultural raw material prior to 1956, when oil was discovered in the region, is now a major importer of food (Ojo and Adebayo, 2012). As interest in the oil sector increased, an opposite trend was observed in agriculture. On the other hand, most farmers in sub-Saharan Africa are plagued with high level of illiteracy; poor or inadequately information on modern, efficient techniques in agriculture; poor and insufficient supply of agricultural tools, machinery and much needed agricultural extension services.

Another major factor affecting decline in agricultural productivity in SSA is the limitation imposed upon farmers from unfavorable environment and climatic conditions (Wedding and Tuttle, 2013). According to the World Bank (2000), the debilitating food security problems in Africa is greatly linked to data which state that $85 \%-90 \%$ of agriculture relies on rainfall, contributing $35 \%, 40 \%$ and $70 \%$ to its gross national product (GNP), exports and employment respectively. For example, much of the countries in eastern Africa, particularly in the horn, suffer from unfavorable conditions such as drought and climatic (FAO, 2015). This factor has seriously undermined efforts geared at overcoming the challenges facing the region in terms of food security and nutrition (FAO, 2015). Unlike natural condition like climate, some anthropogenic propellants of food insecurity in SSA are particularly associated with activities pertaining to terrorism, civil strife and insecurity, land ownership disputes and so on. For example the numbers of undernourished people have more than doubled due to the civil strife in middle Africa (FAO, 2015). In Nigeria, due to the activities of the terror sect, Boko Haram, the malnutrition situation in the north eastern part of the country has been termed to be "critical" (Vahyala et al., 2016; UNICEF, 2017).

As a result of the challenges highlighted above, complications associated with malnutrition and poor diet related noncommunicable diseases become prevalent and are present in most countries in SSA. Cases of severe acute malnutrition amongst children there have been extremely high in the North Eastern Nigeria, particularly in Borno State. In the North Eastern Nigeria, an estimate by UNICEF states that about 400,000 are at risk of suffering severe acute malnutrition, with a mortality rate of $20 \%$ (i.e., one in five) (UNICEF, 2017). A report by FAO in 2006 projects that over the next two decades, hunger levels will increase in SSA, with estimates pointing out that one in four persons in Africa is undernourished (FAO, 2015). This course is set to be aggravated unless some quick and timely measures are taken. Hence, it will take conscious and purposeful changes in the perceived "normal" course of events to be able to make improvements in the food insecurity and consequent poverty issues in SSA today (Boon, 2009).

Although some drastic measures have been either proffered and/or taken in tackling food insecurity in Africa, such as peace building in conflict stricken regions, provision of better agriculture friendly policies and governance, empowerment of farmers and boosting agricultural techniques in farming and many more, however, statistics of the region being food secured are not pleasant and a lot of work still needs to be done. In lieu of this problem, this study aims to examine the suitability of use of genetically modified organisms (GMOs) as a probable long lasting solution to tackling the problem of food insecurity in SSA. Naturally, genetically modified food arose out of the determination to escape from the imminent famine and hunger in the face of exploding population particularly in Asia and Africa. The crisis gave rise to the green revolution whose 'father' was Norman Borlaug (19142009).

\section{Bioprocess engineering}

Bioprocess engineering involves the practical use of technology to bioprocesses with the aim of mass producing new products such as food and pharmaceuticals. It also involves the use of chemicals in changing the physiological traits of biosystems by tampering with the genetic makeup of the organism. This could 
be achieved by inserting genetic materials that are extraneous to humans to make up for genes which possess high functionality that may have been lost thus leading to severe health conditions. It involves the application of biotechnology in specific processes, instrumentation and stages in the manufacture of biological products (Ladisch and Kohlmann, 1992).

Engineering is a key field in the commercialization of biotechnological ideas into viable products. This is evident in the production of food and bioactive proteins. Engineers are responsible for designing and scale up of biofermentors to produce commercial quantities of genetically modified cells needed to drive the production of these bioproducts as well as develop techniques that can be used in separating and purifying biomolecules (NAS, 1992). The concepts guiding bioprocess engineering are situated in the biosciences. These include: genetics, molecular biology and biosystem control. These concepts enable the bioprocess engineer seek out genes of industrial importance as well as envisage their end products for the purpose of solving problems crucial to the survival of man. Areas such as drug development, environmental cleanup and food production are just a few of the huge benefits humanity has come to enjoy as a result of bioprocess engineering. Also, molecular biology has made it easy to manipulate the gene in order to achieve increased functionalities be it in microbes, animals or human cells. Biosensors are also a huge part of monitoring biosystems in bioprocess engineering (Ladisch, 2005).

\section{(GMO's) \\ Genetically modified organisms}

Genetically modified organisms (GMOs) can be referred to as organisms (such as microorganisms, plants, and/or animals) in which alterations in the genetic material (DNA) has been made in ways that do not happen naturally by natural recombination and/or mating (WHO, 2015). This utilizes technology often referred to as "genetic engineering", and food manufactured using this technology is referred to as genetically modified (GM) foods (WHO, 2015). GM foods are therefore nutritious substances designed, created and produced using molecular biology techniques for consumption by humans or animals (Taire, 2003). For example, gene modification permits the genetic engineer design a plant to his/her specifications and desires (Olaniyan et al., 2007), it involves selection of individual desirable genes and facilitating their transfer from one organism (host) into another (recipient), of the same species or between nonrelated species, also referred to as transgenesis (Elliott and Madan, 2016). This is done to ensure the expression of that isolated gene in the recipient. Compared to other techniques like mutagenesis, which searches for desirable changes in an organism, transgenesis is much more specific and targeted (Nathaneal, 2015; Elliott and Madan, 2016).

Genetic engineering technology has revolutionary potentials in agriculture. GM foods cultivated today have come a long way through series of experimentation and safety testing, the world's first commercially available GMO was the FlavrSavr, a tomato variety genetically modified to slow down ripening and preserve flavor, approved by the United States for cultivation in 1994 (Elliott and Madan, 2016). Ever since, the GMO pipeline has expanded to include and explore different traits introduced into a range of crops grown in 28 developed and developing countries (James, 2014). Most common characteristic traits explored in genetic modification of foods include the production of herbicide resistance in crops; insect resistance in crops; making crops more disease resistant; production of hardy crops that can survive where environmental conditions are less favourable; modification of crops to have longer storage capacity and so on (Altieri and Rosset, 1999; Hammer, 2003; Ronald 2011; Parisi et al., 2016). However, according to James (2014), crops such as; maize, soybeans, rapeseed and cotton, and the traits; insect resistance and herbicide tolerance, dominate the GMO landscape. In addition to GM Foods, there are several processed foods produced from 
enzymes sourced from genetically engineered microorganisms. A few applications involve the use of alphaamylase from bacteria to convert starch into simple sugars; chymosin from bacteria or fungi which causes the clotting of milk protein for making cheeses; Juice clarity obtained from the pectinase enzyme from fungi (Ibiam and Okoi, 2012).

\section{GMO engineering process}

There are several available protocols and methods applied for the transfer of DNA into cells, their applicability may however be general or source specific. The strategies and approaches used are often collectively termed recombinant DNA technology (Han, 2004). The term "recombinant DNA technology" comprises of an arsenal of laboratory methods used in production of a GMO and summarily includes the basic steps of; identification and isolation of the genetic trait of interest and its nucleotide sequence (gene); production of gene copies via amplification mechanisms; gene association with suitable promoter and poly A sequence and its insertion into a vector (such as plasmids); multiplication of the plasmid-bacteria construct and its subsequent recovery of construct for injection; transfer of the construct into the recipient tissue; integration and expression of gene in recipient genome; and inheritance of the gene through other generations (Beardmore and Porter, 2003). Two principal enzymes used in recombinant DNA technology are the; restriction endonucleases (biological scissors) used to cleave DN molecules at specific points into fragments of defined sizes; and the ligases (biological glue) to join the insert and vector together (Davies and Ollier, 2001; Han, 2004; Traavik et al., 2007). The vector contains a DNA sequence, origin of replication (ori) that enables it to be replicated in the bacteria, Escherichia coli, they include biolistics, $\mathrm{CaCl}_{2}$ - heat shock treatment or electroporation, transformation and conjugation, other processes include; gene silencing and gene splicing, lipofection, microinjection, calcium phosphate precipitation, vectors and protoplast transformation among others (Han, 2004; Olaniyan et al., 2007).

\section{The global distribution of GM crops}

The acceptability, use and application of GM foods have seen considerable growth in recent years. According to the International Service for the Acquisition of Agri-biotech Applications (ISAAA), an estimated18 million farmers in 28 countries planted 179.7 million hectares (444 million acres) in 2015 (ISAAA, 2015), showing a 100fold increase from 1.7 million hectares in 1996 to 179.7 million hectares in 2015 as well as an increase in farmers by up to 17 to 18 million. This huge data indicates that GMO's have a huge role to play in food security if the technology is instantly embraced. Of the aforementioned 28 countries, 10 are high-income countries and 18 low and middle income countries with the United States, Argentina and Brazil contributing over $75 \%$ of the total area cultivated with GM crops (James, 2014). It was in 2012 where developing countries first grew a majority (52\%) of the total GM harvest. 17.3 million farmers grew GM crops; around $90 \%$ were small holding farmers in developing countries (ISAAA, 2012). Recently, ISAAA have reported that developing countries, led by Brazil, India, and China respectively have recently surpassed developed countries in terms of the land area planted to GM crops, accounting for a $82 \%$ of it (ISAAA, 2015).

The five leading developing countries cultivating biotech crops across three continents include Brazil and Argentina (South America) India and China (Asia), and South Africa (SSA). These countries alone are responsible for growing nearly half (48\%) of the total global GM crops. However, from the developing countries in Africa, Burkina Faso, South Africa, and Sudan approve the cultivation of GM crops. These countries cultivate $\mathrm{Bt}$ cotton, whereas, South Africa also grows GM varieties of maize and soybeans inclusive (Table 1). Together they account for less than $2 \%$ of the total area worldwide cultivated to GM crops (ISAAA, 2015; Elliott and Madan, 2016). 
Table 1. Global Area of Biotech Crops in 2015, by country (million hectares**).

\begin{tabular}{|c|c|c|c|}
\hline Rank & Country & $\begin{array}{c}\text { Area (million } \\
\text { hectares)** }\end{array}$ & Biotech crops \\
\hline 1 & USA* & 70.9 & $\begin{array}{l}\text { Maize, soybean, cotton, canola, sugar } \\
\text { beet, alfalfa, papaya, squash, potato }\end{array}$ \\
\hline 2 & Brazil* & 44.2 & Soybean, maize, cotton \\
\hline 3 & Argentina* & 24.5 & Soybean, maize, cotton \\
\hline 4 & India* & 11.6 & Cotton \\
\hline 5 & Canada* & 11.0 & Canola, maize, soybean, sugar beet \\
\hline 6 & China* & 3.7 & Cotton, papaya, poplar \\
\hline 7 & Paraguay* & 3.6 & Soybean, maize, cotton \\
\hline 8 & Pakistan* & 2.9 & Cotton \\
\hline 9 & South Africa* & 2.3 & Maize, soybean, cotton \\
\hline 10 & Uruguay* & 1.4 & Soybean, maize \\
\hline 11 & Bolivia* & 1.1 & Soybean \\
\hline 12 & Philippines* & 0.7 & Maize \\
\hline 13 & Australia* & 0.7 & Cotton, canola \\
\hline 14 & Burkina Faso* & 0.4 & Cotton \\
\hline 15 & Myanmar* & 0.3 & Cotton \\
\hline 16 & Mexico* & 0.1 & Cotton, soybean \\
\hline 17 & Spain* & 0.1 & Maize \\
\hline 18 & Colombia* & 0.1 & Cotton, maize \\
\hline 19 & Sudan* & 0.1 & Cotton \\
\hline 20 & Honduras & $<0.1$ & Maize \\
\hline 21 & Chile & $<0.1$ & Maize, soybean, canola \\
\hline 22 & Portugal & $<0.1$ & Maize \\
\hline 23 & Vietnam & $<0.1$ & Maize \\
\hline 24 & Czech Republic & $<0.1$ & Maize \\
\hline 25 & Slovakia & $<0.1$ & Maize \\
\hline 26 & Costa Rica & $<0.1$ & Cotton, soybean \\
\hline 27 & Bangladesh & $<0.1$ & Brinjal/Eggplant \\
\hline \multirow[t]{2}{*}{28} & Romania & $<0.1$ & Maize \\
\hline & Total & 179.7 & \\
\hline
\end{tabular}

* 19 biotech mega-countries growing 50,000 hectares, or more, of biotech crops.

** Rounded off to the nearest hundred thousand.

Source: Clive James (ISAAA, 2015).

\section{Advantages and disadvantages on the use of GM foods}

The controversy over the acceptability and use of genetically modified foods has been raging for over two decades, evoking opposing views particularly from the scientific circles and other communities (Qaim, 2010; Amin et al., 2011), the principal bone of contention being whether genetically modified foods has a negative effect on the human body. Amongst the scientific circles, there is a broad consensus that well-regulated GMOs are not more risky than the conventionally bred crops and are safe to eat (Key et al., 2008; Ronald, 2011).

Till date the subject of safety in/of GM foods remains controversial and unresolved. At the initial stage, increase in productivity was the target. It is therefore not known how far the initial research team went in subjecting the investigation to proper long term safety scrutiny. With a substantial input of chemical fertilizers and agro chemicals, the level of postharvest residual contaminants in GM foods and the overall economics of the whole scheme continue to invite scathing criticisms. It is noteworthy that GM food remains one of 
the areas in which molecular genetics is applied in bioprocess engineering with the initial intention of exploiting desired genes to improve crop yield and food quality.

Discussed below and some of the perceived pros and cons associated with GM foods:

\section{Pros}

1. Herbicide tolerant/insect resistant crops. The principal benefit from herbicide tolerant crops is the reduction in labor required for land weeding. In developing countries with less access to chemical controls, farmers spend fewer hours weeding (Thompson, 2015; Elliott and Madan, 2016).

Insect pest are major threats to agriculture, statistics in the United States alone estimated loss of crop and forest production losses from invasive insects and pathogens at almost US\$ 40 billion per year (Pimentel et al., 2005). Studies have shown that developing countries, SSA in particular, are most vulnerable to invasive crop pest species (Paini et al., 2016). However, the use of insect resistant improved crop varieties allows farmers to manage pests with lower chemical use, which again saves on labor and other input costs.

2. Economic benefits: Over the past two decades, about \$ 133 billion in agriculture worth has been added to the global economy courtesy of GM foods (Klümper and Qaim, 2014). It has on the average, reduced chemical pesticide use by 37 percent, increased crop yields by 22 percent, and increased farmer profits 68 percent during the 20 year period of 1995 to 2014.

3. Human health: A decrease in the use of pesticides associated with insect resistant crops could result in reduction in chemical poisoning of farmers and greatly improve soil biodiversity (Barrows et al., 2014). In addition to this, the genetic modification of plants to provide therapeutic relief have been reported (Kramkowska et al., 2013). Research has led to success in the transference of genes implicated in the expression of antigens of bacteria and viruses directly into nuclei or chloroplast of plant cells (Yonekura and Saito, 2006; Ubalua, 2009). Examples of such cultivable edible vaccines have been developed in choice GM foods like soybeans, rice, potatoes, maize, capable of expressing antigens which immunize against effects of infectious organisms such as Escherichia coli toxins, rabies, infections with Helicobacter pylori bacteria, and viral type $B$ hepatitis (Yonekura and Saito, 2006; Ubalua, 2009; Verma et al., 2011; Kramkowska et al., 2013).

4. Environment: The use of biotech engineered crops also confers some benefit to the environment. Resultant higher farm yields of GM crops leads to land saving, which may be beneficial in mitigating effects of climate change. The use of herbicide tolerant GM crops not only eliminates the rigors involved in land tilling but also helps in preserving soil quality, fewer carbon emissions, reduces soil surface runoff and consequently prevents land degradation (Barrows et al., 2014).

5. More nutritious foods; Biotechnological improvement techniques have conducted modifications in transgenic food, to alter specific content of proteins, lipids and carbohydrates to make food more nutritious (Kramkowska et al., 2013). One significant stride made in this regard is the introduction of "golden rice", whose genome has been modified to enhance the level of $ß$-carotene to help prevent Vitamin A deficiency, responsible for normal sight and body resistance (Hug, 2008; Key et al., 2008; Qaim, 2010; Sheetal, 2014). Rice enrichment utilized the seclusion and transfer of genes from the bacterium Erwinia uredovora and flower, Narcissus jonquilla (jonquil) directly into grains (Kramkowska et al., 2013).

Other pros to the use of GM foods include; the use of drought tolerant GM crops; improves shelf life of crops. Table 2 shows some GM foods and their benefits of modification. 
Table 2. Advantages of select GM foods.

\begin{tabular}{ll}
\hline Food & Modification benefits \\
\hline${ }^{*}$ Bt Cotton and Maize & Insect resistant \\
& Herbicide tolerant \\
${ }^{+}$Rice & Higher content of $\beta$-carotene \\
& Higher iron bioavailability \\
& Higher content of dry matter \\
${ }^{+}$Tomato & Delayed ripening process \\
& Aroma intensification \\
& Virus resistance \\
& (cow, goat, sheep) \\
${ }^{+}$Milk & Increased tolerance for high temperature \\
& Modified casein content \\
& Lower lactose content \\
& Higher amylopectin content \\
${ }^{+}$Potato & Cyclodextrin production \\
& Resistance to viruses and potato beetle \\
& Lower alkaloids content \\
${ }^{+}$Transgenic fishes & Faster growth rate \\
(carp, salmon, trout) & \\
\#Tobacco & Modified to contain little nicotine \\
\#Rapeseed & More resistant to pesticides \\
& Free from erucic acid \\
\#Canola & Resistant to pesticides \\
& May be used in oil products, baked goods and snacks \\
\#Papaya & Modified to be more virus resistant \\
\hline
\end{tabular}

Sources: ${ }^{+}=$Kramkowska et al. (2013); $\#=$ Sheetal (2014);* = Elliott and Madan (2016).

\section{Cons}

Several opposing views on consumption of GM foods still persist, majority are associated with uneasiness and anxiety of "genetic modifications" to food, particularly relating to ethical concerns on negative consequences of molecular biology protocols "interrupting" with processes of natural recombination. Others are associated with ethical principles of gene manipulation, a few might be related to the complexity of the process involved (Domingo, 2007; Ekici and Can, 2012). Some of the arguments are discussed below:

1. Proliferation of resistant pests and super weeds: Investigations by Barrows et al. (2014) summarized that herbicide tolerant GMOs may cause the acceleration of the emergence of much more tolerant pests and weeds. This may be exacerbated by activities of farmers with an over reliance on the use of glyphosate alongside herbicide tolerant GM crops, which may therefore cause the proliferation of superweeds tolerant to chemicals (Gilbert, 2013). Proliferation of superweeds may require application of larger doses of herbicides to destroy the weeds (Kramkowska et al., 2013). However, seed companies' response to this is to stack traits so that new varieties of GM foods can tolerate more toxic chemicals (Elliott and Madan, 2016).

2. Exploitative tendencies: According to Giddings et al. (2016), there are arguments that GMOs would only be of beneficial to much industrialized nations of the world, and hence, may price farmers from less industrialized nations, for example, in Africa, out of the GM foods market.

3. Risk of food allergy: The term allergy is used to refer to a condition of hypersensitivity to food substance evoking the immune system to cause 
diverse reactions. About $2 \%$ and $6 \%$ of the world's adult and children respectively are estimated to be allergic to one or more food components already (Bernstein et al., 2003; D'Agnolo, 2005). Concerns about the synthesis of new "proteins" in food, obtained from genes of another organism may form a new amino acid structure that might acts as possible allergens. Some widely publicized cases of food allergies involving transgenic plants include the Aventis transgenic maize (utility name: Star Link) and transgenic methionine enriched soyabeans (genes isolated from Brazil nuts) (Bernstein et al., 2003; Key et al., 2008; Batista and Oliveira, 2009; Dona and Arvanitoyannis, 2009). Reported symptoms to consumption of theses transgenic maize include headaches, diarrhoea, nausea and vomiting (Kramkowska et al., 2013).

4. Development of resistance to antibiotics: An early stage of transgenesis usually utilizes bacteria to be used as markers or functioning as elements distinguishing transformed cells from non-transformed cells which rejected the coding alleles. However, the bacteria are used play double roles; as markers of transformed cells observed physiologically by resistance to antibiotic. Uses of antibiotic resistant bacteria are markers of transformants may pose very costly risks. It could result in transfer of resistance genes to normal bacterial flora, including pathogenic bacteria in the human and animal guts. The use of other genetic markers for confirming transformants is required (D'Agnolo, 2005; Craig et al., 2008; Hug, 2008). Genes which pose no risks to humans or animals have been suggested, such as nptII (Paoletti et al., 2008).

Some other commonly perceived potential negative effects of GM foods include its potential effect on man's health (synthesis of toxic compounds), environmental (unintended transfer of transgenes through pollination), playing with nature by violation of natural organisms' intrinsic values, biopiracy, and so on (Hammer, 2003; Kramkowska et al., 2013).

\section{Hindrances to the use of GMOs in Africa}

The European Union is a major destination for the import of raw food items from developing countries, including Africa, however, as at October 2015, bans on cultivation of GM crops were placed by 19 European countries (Giddings, 2016). This ban scenario therefore provides most crucial propellant through which European anti-GM forces have indirectly hindered the use of GMO use in the Africa, enforced by the strict regulation of the import of GM products (Elliott and Madan, 2016).

In addition to the European Union's policies, other influences hindering the use of GM foods in SSA include:

- The Cartagena Protocol on Biodiversity, signed by 170 countries endorses a precautionary approach stating that countries exporting GMOs for food and feed use must notify importing countries those products "may contain living GMOs (Chambers et al. 2014; Hagen and Weiner, 2000).

- The second is the African Union Model Law on Safety in Biotechnology (formerly the African Model Law on Safety in Biotechnology), which is designed to harmonize biosafety legislation across the continent (ACB, 2009).Influenced by these policies in the early 2000s, several Sub-Saharan African countries imposed bans on GMOs, including cultivation and imports for food, feed, and industrial use (ACB, 2009; Chambers et al. 2014; Elliott. and Madan, 2016).

- $\quad$ Other hindrances probably preventing SSA's use of GMOs in fostering food security in the region may include weak infrastructure and poorly functioning markets (for both inputs and outputs) (Elliott and Madan, 2016).

- Extreme fears have attracted caution in wholesale embrace of GM foods in Nigeria (Olaniyan et al 2007) and Kenya (Owino 2012). 
Of recent, the appropriate government agency issued two permits for the Commercial Release and placing on Market of genetically modified cotton and the confined field trial of maize in Nigeria.

The two permits include: 'Permit for Commercial Release/Placing on Market of Cotton (MON15985) genetically modified for leptidopteran insect pest resistance' with Permit No: NBMA/CM/IM/001 and 'Permit for Confined Field Trial (CFT) of Maize $(\mathrm{NK603}$ and MON89034 $\times$ NK603) genetically modified for insect resistance and herbicide tolerance' with Permit No: NBMA/CFT/001. As at 2017 the grantee has not commenced trials. Earlier, Nigeria also sought to improve, through genetic modification, $\mathrm{Bt}$ cowpea, sorghum (for phytate removal) and rice all at various stages of demonstrations and trials involving appropriate government designated institutions. The approval to improve on the cassava starch stability, a process intended to enhance market value of the product has just been given. In spite of the seeming openness in engaging the public many opponents have called for the repeal of the National Biosafety law and the scrapping even of the National Biosafety Commission claiming that the two were not packaged enough to address genuine feelings and concern of informed Nigerians.

Biological control option and organic agriculture are fast gaining attraction due to a substantial reduction in chemical input both in farm and in store. Livestock and plant protectants as well as stabilizers and growth enhancers are increasing their presence in the market. Although some safety and environmental stability issues still exist in biological intervention, the general wisdom is that this field is promising and needs encouragement. In cultivating nontoxigenic strains, detailed technical input comprising many departments of bioprocess engineering is involved. Most European Union countries no longer patronized chemical-invaded agro-products due to the safety concerns lending credence to the continuing embrace of organic production in developing countries. The incidents of rejects, rapid alerts and trade bans imposed on African and other developing countries due to unacceptably high pesticides and mycotoxin levels on the latter's exports (like beans and melon) may gradually be coming to an end in not too distant future.

\section{Conclusion}

In alleviating food insecurity, African nations need to show commitment and take deliberate steps in boosting the agricultural sector and this may involve amending policies and agricultural institutional weaknesses which promulgates reduced incentives to adequately invest in agricultural research and development in the region. Biotechnology through process engineering should be explored only after it has taken care of long term uncertainties and possibilities particularly when microbes are concerned. Mutation potentials should be concluded in the bioreaction stage and enough time spent to observe reversal of roles. Although food insecurity occurs in sub Saharan Africa, it takes effect proaction to understand the causes e.g., flooding, drought, bad processing habits to arrive at sustainable security. An inclusive approach in which small holder farmers are involved in available user and pocketfriendly interventions may be an attraction in the present circumstance. This study however discusses the problem of food security in SSA and examines the advantages and disadvantages of Biotech improved foods as probable suitable alternatives in tackling the food security in the region. The use of GM crops by farmers has been growing worldwide, although the involvement of farmers in SSA has however been minimal, it is a technology with great potentials, that if properly harnessed can create a huge aversion of the looming food crisis problem in SSA and also boost the economic situation in the region.

Recently, it's been estimated that up to $\$ 1.5$ trillion is lost by low and lower middle income nations (particularly in SubSaharan African countries) as a result of restrictions to the use of agricultural biotech 
innovations (Giddings et al., 2016), thus acting as a barrier to development in poor countries. This study therefore recommends that the African Union weighs the option of organic agriculture and practicality of such, in light of the need to consider the economic status of the average small holder farmer. If GM foods are being rejected elsewhere, why will SSA be excited by it? When farmers need to regularly patronize the supplier for new sets of seeds each planting season, then the whole scheme naturally invites curiosity and scrutiny. The multi-billion dollar GM project must come up with superior argument against cultural practices and use of natural seeds. At all times, issues of yield and long-term safety must be equally weighed. This is where we stand to readdress the pros and cons of exploring GM foods as suitable tools to ameliorate food crisis in SSA and the opportunity to significantly improve its economy, productivity and reduce problems of malnutrition.

\section{Conflict of interests}

The authors declare that there are no conflicts of interest.

\section{References}

ACB - African Centre for Biosafety. The revised African model laws on biosafety and the African biosafety strategy. Arusha, Tanzania: ACB, 2009. (Briefing paper, 9). Available from: <http://acbio.org.za/wpcontent/uploads/2015/02/AU_Biosafetybrief.pdf>. Accessed on: May 23, 2017.

Adegbola, J. A.; Bamishaiye E. I.; Daura, A. M. Food security in Nigeria: government's intervention and the place of effective storage. Asian Journal of Agriculture and Rural Development, v. 1, no. 2, p. 56-63, 2011.

Agyare-Kwabi, P. Women and Food Security in West Africa. Proceed of the Seminar on Women, Integrated Farming Systems and Food Security in West Africa, Accra, 2003.

Altieri, M.; Rosset, P. Ten reasons why biotechnology will not ensure food security, protect the environment and reduce poverty in the developing world. AgBioForum, v. 2, no. 3/4, p. 155-162, 1999. Available from: <http://www.agbioforum.org/v2n34/v2n34a03altieri.pdf $>$. Accessed on: May 23, 2017.

Amin, L.; Hamdan, F.; Hashim, R.; Samani, M. C.; Anuar, N.; Zainol, Z. A.; Jusoff, K. Risks and benefits of genetically modified foods. African Journal of Biotechnology, v. 10, no. 58, p. 12481-12485, 2011.

Barrows, G.; Steven, S.; David, Z. Agricultural biotechnology: the promise and prospects of genetically modified crops. The Journal of Economic Perspectives, v. 28, no. 1, p. 99-120, 2014. Available from: <http://pubs.aeaweb.org/doi/pdfplus/10.1257/je p.28.1.99>. Accessed on: May 23, 2017.

Batista, R.; Oliveira, M. M. Facts and fiction of genetically engineered food. Trends in Biotechnology, v. 27, no. 5, p. 277-286, 2009. https://doi.org/10.1016/j.tibtech.2009.01.005

Beardmore, J. A.; Porter, J. S. Genetically modified organisms and aquaculture. Rome: FAO, 2003. (FAO Fisheries Circular, 989). Available from: <http://www.fao.org/docrep/ 006/Y4955E/Y4955E00.HTM>. Accessed on: May 23, 2017.

Bernstein, J. A.; Bernstein, L. I.; Bucchini, L.; Goldman, L. R.; Hamilton, R. G.; Lehrer, S. Clinical and laboratory investigation of allergy to genetically modified foods. Environmental Health Perspectives, v. 111, no 8, p. 11141121, 2003. Available from: $<$ https://www.ncbi.nlm.nih.gov/pmc/articles/PM C1241560/pdf/ehp0111-001114.pdf>. Accessed on: May 23, 2017.

Boon, E. K. Food security in Africa: challenges and prospects. In: Boon, E. K. (Ed.). Regional sustainability review: Africa. Abu Dhabi: Unesco/EOLSS, 2009. p. 23-53. v. 1.

Chambers, J. A.; Zambrano, P.; Falck-Zepeda, J.; Gruère, G.; Sengupta, D.; Hokanson, K. GM agricultural technologies for Africa: a state of affairs. Washington: International Food Policy Research Institute, African Development Bank, 2014.

Craig, W.; Tepfer, M.; Degrassi, G.; Ripandelli, D. An overview of general features of risk assessment of genetically modified crops. Euphytica, v. 164, no. 3, p. 853-880, 2008. https://doi.org/10.1007/s10681-007-9643-8

D’Agnolo, G. GMO: Human health risk assessment. Veterinary Research Communications, v. 29, suppl. 2, p. 7-11, 2005. https://doi.org/10.1007/s11259-005-00037

Davies, R.; Ollier, S. Allergy: the facts. Oxford: Oxford University Press, 2001. 
Domingo, J. L. Toxicity studies of genetically modified plants: a review of the published literature. Critical Reviews in Food Science and Nutrition, v. 47, p. 721-733, 2007. https://doi.org/10.1080/10408390601177670

Dona, A.; Arvanitoyannis, I. S. Health risk of genetically modified foods. Critical Reviews in Food Science and Nutrition, v. 49, p. 164-175, 2009. https://doi.org/10.1080/104083907018 55993

Ekici, K.; Can, S. Y. A. Perspective on genetically modified food crops. African Journal of Agricultural Research, v. 6, no. 7, p. 1639-1642, 2012. https://doi.org/10.5897/ AJAR10.284

Elliott, K.; Madan, J. Can GMOs deliver for Africa? Washington, DC: Center for Global Development, 2016. (CGD Policy Paper 080). Available from: <https://www.cgdev.org/sites/ default/files/CGD-Policy-Paper-80-ElliottMadan-GMOs-for-Africa.pdf $>$. Accessed on: Aug. 25, 2017.

FAO. Food production: the critical role of water, in world food summit. Rome: FAO, 1996. (Technical background documents 6-11, v. 1).

FAO. Food security and agricultural development in Sub-Saharan Africa. Rome: FAO, 2006. (Policy Brief No. 1).

FAO. Regional overview of food insecurity: African food security prospects brighter than ever. Accra: FAO, 2015.

Giddings, L. V.; Atkinson, R. D.; Wu, J. U. Suppressing growth: how GMO opposition hurts developing nations. Washington: Information Technology and Innovation Foundation, 2016. Available from: $<$ http://www2.itif.org/2016-suppressinginnovation-gmo.pdf $>$. Accessed on: Aug. 25, 2017.

Gilbert, N. Case studies: a hard look at GM crops. Nature, v. 497, p. 24-26, 2013. https://doi.org/10.1038/497024a

Hagen, P. E.; Weiner, J. B. The Cartagena Protocol on Biosafety: new rules for international trade in living modified organisms. The Georgetown International Law Review, v. 12, no. 697, p. 1-21, 2000.

Hammer, M. Writing nature: discourses of ecology. The economics of genetically modified foods. Stanford, UK: University of Standford, 2003. Available from: $<$ https://web.stanford.edu/ cbross/Markrp.html >. Accessed on: Aug. 25, 2017.
Han, L. Genetically modified microorganisms: development and applications. In: Parekh, S. R. (Ed.). The GMO handbook: genetically modified animals, microbes, and plants in biotechnology. New York: Springer, 2004. p. 29-51. https://doi.org/10.1007/978-1-59259801-4_4

Hilderink, H.; Brons, J.; Ordoñez, J.; Akinyoade, A.; Leliveld, A.; Lucas, P.; Kok, M. Food security in sub-Saharan Africa: an explorative study. The Hage: PBL Netherlands Environmental Assessment Agency, 2012. Available from: <http://www.pbl.nl/sites/ default/files/cms/publicaties/PBL_2012_Explori ng food security_555075001_0.pdf $>$. Accessed on: Aug. 25, 2017.

Hug, K. Genetically modified organisms: do the benefits outweigh the risks? Medicina (Kaunas), v. 44, no. 2, p. 87-99, 2008. Available from: <http://medicina.lsmuni.lt/ med/0802/0802-01e.pdf $>$. Accessed on: Aug. 25, 2017.

Ibiam, O. F. A.; Okoi, I. A. Genetically modified food: health benefits and risks. International Journal of Agricultural Science Research, v. 1, no. 2, p. 24-33, 2012.

Idris, N. M.; Majid, M. R.; Choji, I. D. A comprehensive approach to drought and desertification in Nigeria, Management of Environmental Quality: An International Journal, v. 19, no. 6, p. 690-704, 2008. https://doi.org/10.1108/14777830810904911

ISAAA - International Service for the Acquisition of Agri-Biotech Applications Annual report Executive Summary, 2012.

ISAAA - International Service for the Acquisition of Agri-Biotech Applications. Executive Summary - Global Status of Commercialized Biotech/GM Crops: 2015. 2015.

James, C. Global Status of Commercialized Biotech/GM Crops: 2014. Ithaca, NY: International Service for the Acquisition of Agri-Biotech Applications, 2014. (ISAAA Brief 49).

Key, S.; Julian K.-C. M.; Pascal, M. W. D. Genetically modified plants and human health. Journal of Royal Society of Medicine, v. 101, p. 290-298, 2008. https://doi.org/10.1258/jrsm. 2008.070372

Klümper, W.; Qaim, M. A meta-analysis of the impacts of genetically modified crops. PLoS ONE, v. 9, no. 11, 2014. https://doi.org/ 10.1371/journal.pone.0111629 
Kramkowska, M.; Grzelak, T.; Czyżewska, K. Benefits and risks associated with genetically modified food products. Annals of Agricultural and Environmental Medicine, v 20, no. 3, p. 413-419, 2013. Available from: $<$ http://www.aaem.pl/pdf-71952-9179?

filename=Benefits and risks.pdf $>$. Accessed on: Aug. 25, 2017.

Ladisch, M. R. Bioprocess Engineering (Biotechnology). New York: John Wiley and Sons, 2005. (Van Nostrand's Scientific Encyclopedia).

Ladisch, M. R.; Kohlmann, K. L. Recombinant human insulin, Biotechnology Progress, v. 8, no. 6, $\quad$ p. 469-478, 1992. https://doi.org/10.1021/bp00018a001

Maharjan, K. L.; Chhetri, A. K. Household food security in rural areas of Nepal: relationship between socio-economic characteristics and food security status. Proceed of the International Association of Agricultural Economist Conference, Gold Coast Australia, 2006.

Markov, S. A. Bioprocess Engineering. In: Franceschetti, D. R (Ed.). Applied science. Amenia, NY, Salem Press, 2012. v. 1, p. 240245.

NAS - National Academy of Sciences. Putting biotechnology to work: bioprocess engineering. Washington, DC: National Academy of Sciences, 1992.

Nathaneal, J. It's practically impossible to define 'GMOs'. 2015. Available from: $<$ http://grist.org/food/mind-bomb-itspractically-impossible-to-define-gmos/>. Accessed on: Mar. 26, 2017.

Ojo, E. O.; Adebayo, P. F. Food security in Nigeria: an overview. European Journal of Sustainable Development, v. 1, no. 2, p. 199222, 2012. Available from: <https://ecsdev.org/ojs/index.php/ejsd/article/vi ew/24/18>. Accessed on: Mar. 24, 2017.

Olaniyan, S A.; Bakare, A. A.; Olajumoke A. M. Genetically Modified Foods in Nigeria: A long-lasting solution to hunger. Estud. Biol., v. 29, no. 67, p. 191-202, 2007.

Otaha, I. J. Food insecurity in Nigeria: way Forward. African Research Review, v. 7, no. 4, p. 26-35, 2013. http://dx.doi.org/10.4314/ afrrev.v7i4.2

Owino, O. Scientists torn over Kenya's recent GM food ban. Nature, 2012. https://doi.org/10.1038/nature.2012.11929

Paini, D. R.; Sheppard, A. W.; Cook, D. C.; De Barro, P. J.; Worner, S. P.; Thomas, M. B. Global threat to agriculture from invasive species, PNAS, v. 113, no. 27, p. 7575-7579, 2016. https://doi.org/10.1073/pnas.1602205113

Paoletti, C.; Flamm, E.; Yan, W.; Meek, S.; Renckens, S.; Fellous, M. GMO risk assessment around the world: some examples. Trends in Food Science \& Technology, v. 19, p. S70S78, 2008. https://doi.org/10.1016/j.tifs. 2008.07.007

Parisi, C.; Tillie, P.; Rodríguez-Cerezo, E. The global pipeline of GM crops out to 2020. Nature Biotechnology, v. 23, no. 1, p. 31-36, 2016. https://doi.org/10.1038/nbt.3449

Pimentel, D.; Zuniga, R.; Morrison, D. Update on the environmental and economic costs associated with alien-invasive species in the United States. Ecological Economics, v. 52, no. 3, p. 273-288, 2005. https://doi.org/10.1016/ j.ecolecon.2004.10.002

Qaim, M. Benefits of genetically modified crops for the poor: Household income, nutrition, and health. New Biotechnology, v. 27, no. 5, p. 552-557, 2010. https://doi.org/10.1016/j.nbt. 2010.07.009

Ronald, P. Plant genetics, sustainable agriculture and global food security. Genetics, v. 188, no. $1, \quad$ p. 11-20, 2011. https://doi.org/10.1534/genetics.111.128553

Ronald, P. The truth about GMOs. Boston Review, 2013. Available from: $<$ http://bostonreview.net/forum/pamela-ronaldgmo-food>. Accessed in: Jul. 03, 2017.

Sheetal, A. L. Genetically modified foodssolution for food security. International Journal of Genetic Engineering and Biotechnology, v. 5, no. 1, p. 43-48, 2014. https://dx.doi.org/10.1371\%2Fjournal.pone.006 4879

Taire, M. Nigeria: GM foods, keeping the peace in Liberia. 2003. Available from: $<$ http://allafrica.com/stories/200308150295.html >. Accessed on: Aug. 24, 2017.

Thompson, J. A. How genetic engineering can help small farmers in developing countries. Current History, v. 114, no. 775, p. 305-310, 2015.

Traavik, T.; Nielsen, K.; Quist, D. Genetic engineering of living cells and organisms. In: Traavik, T.; Ching, L. L. Biosafety first: holistic approaches to risk and uncertainty in genetic engineering and genetically modified organisms. Penang, Malaysia: Third World Network and GenØk, 2009. p. Available from: <http://genok.no/wp-content/uploads/2013/04/ Chapter-4.pdf>. Accessed on: Aug. 24, 2017. 
Ubalua, A. Transgenic plants: successes and controversies. Biotechnology and Molecular Biology Reviews, v. 4, no. 6, p.118-127, 2009. Available from: $<$ http://www.academicjournals.org/article/articl e1380104928_Ubalua.pdf $>$. Accessed on: Aug. 24, 2017.

UNEP. Africa environment outlook: past, present and future perspectives. Nairobi: UNEP, 2002.

UNICEF. 400,000 children in north-east Nigeria at risk of severe acute malnutrition. Available from: <https://www.unicef.org/nutrition/ nigeria_94178.html. Accessed in: Jul. 03, 2017.

Vahyala, A. T.; Minnessi, G. K.; Kabiru, U. The effects of Boko Haram insurgency on food security status of some selected local government areas in Adamawa State, Nigeria. Sky Journal of Food Science, v. 5, no. 3, p. 12-18, 2016. Available from: <http://www.skyjournals.org/sjfs/pdf/2016/May /Vahyala et al.pdf $>$. Accessed in: Jul. 03, 2017. Verma, C.; Nanda, S.; Singh, R. K.; Singh, R. B.; Sanjay, S. A review on impacts of genetically modified food on human health. The
Open Nutraceuticals Journal, v. 4, p. 3-11, 2014. https://doi.org/10.2174/18763960011040 10003

Wedding, K.; Tuttle, J. N. Pathway to productivity: the role of GMOs for food security in Kenya, Tanzania and Uganda. New York: CSIS - Centre for Strategic and International Studies, 2013. Available from: $<$ https://csis-prod.s3.amazonaws.com/s3fspublic/legacy_files/files/publication/131010_W edding_PathwaysToProductivity_Web.pdf $>$. Accessed on: May 23, 2017.

WHO - World Health Organization. Food genetically modified. Available from: <http://www.who.int/topics/food_genetically_m odified/en/>. Accessed in: Jul. 13, 2017.

World Bank. Africa's Future and the World Bank's Support to It. Washington D.C: World Bank, 2011.

Yonekura, K.: Saito, K. Review: genetically modified plants for the promotion of human health. Biotechnology Letters, v. 28, no. 24, p. 1983-1991, 2006. https://doi.org/10.1007/ s10529-006-9194-4 